\title{
Evidence for cell division in synoviocytes in acutely inflamed rabbit joints
}

\author{
B. HENDERSON, L. E. GLYNN, LUCILLE BITENSKY, AND J. CHAYEN \\ From the Division of Cellular Biology, Kennedy Institute of Rheumatology, Bute Gardens, London W6 7DW
}

SUMMARY DNA synthesis has been measured both by Feulgen cytophotometry, quantified by the DNA synthesis index, and by tritiated thymidine autoradiography, quantified by the labelling index. In the early acute inflammation resulting from the intra-articular challenge of ovalbumin in sensitised rabbits both indices rose considerably, so that at least 1 in 10 synoviocytes was heavily labelled 3 days after challenge. The results are compatible with the concept that even such apparently differentiated synoviocytes are capable of cell division.

Although synoviocyte hyperplasia and extension of the synovial lining are common features of rheumatoid arthritis, the origin of the increased number of synoviocytes is still not known. Thus there is little evidence of mitoses or of an appreciable increase in DNA synthesis in the many specimens of human rheumatoid synovial tissue studied by Mohr et al. ${ }^{1}$ and by Coulton et al. ${ }^{2}$ Although this evidence has been derived from human tissue, which is sampled only late in the disease process, it gives rise to the doubt whether synoviocytes have the capacity to divide, or whether they represent a relatively differentiated, nonmitotic state of some unknown precursor. To investigate whether synoviocytes are capable of mitotic activity the synovium of mature rabbits has been subjected to an experimentally induced immune reaction, and the DNA synthesis in the synoviocytes has been studied.

\section{Materials and methods}

For this study 19 rabbits (Old English strain, obtained from Cheshire Rabbit Farms, Tarporley, Cheshire; weight 2-3 kg) of either sex were used. Thirteen of these were immunised with ovalbumin (Koch-Light: $5 \times$ crystallised) in complete Freund's adjuvant, as in the procedure of Consden et al. ${ }^{3}$ except that $0.5 \mathrm{ml}$, instead of $1.0 \mathrm{ml}$, of the emulsion was used for sensitisation. When the animals had developed hypersensitivity, the right knee was injected with $1 \mathrm{ml}$ of a sterile solution of ovalbumin

Accepted for publication 16 May 1980

Correspondence to Dr B. Henderson, Division of Cellular Biology, Kennedy Institute of Rheumatology, Bute Gardens, London W6 7DW.
$(10 \mathrm{mg} / \mathrm{ml})$ in saline. As controls the left knees were injected with the same volume of sterile saline. The animals were killed 1,3 , or 5 days after the challenge; 3 hours before death $1 \mathrm{ml}$ of tritiated thymidine $\left({ }^{3} \mathrm{HTdR}\right.$; TRA 120 , Amersham: 10 $\mu \mathrm{Ci} / \mathrm{ml})$ in sterile saline was injected intra-articularly into each knee. Of the 13 rabbits that were immunised with Freund's complete adjuvant 5 were killed 1 day after challenge, 4 after 3 days, and 4 after 5 days. The other 6 rabbits were killed at various times; they had been subjected to no experimental procedure.

PREPARATION OF TISSUES

Loewi et al. ${ }^{4}$ showed that, when such small amounts of tritiated thymidine were injected into rabbit joints, no radioactive material was detectable outside the joints. For the present study it was important to check that cells of the bone marrow or peripheral circulation were not being labelled and entering the joint to contribute to the number of labelled cells within the synovial lining. Consequently smears for autoradiography were made from samples of bone marrow removed from the tibia and femur, and from the white cells from blood removed from the central artery of the ear. The blood was taken into heparin tubes and centrifuged $(2000 \mathrm{r} / \mathrm{min} ; 10 \mathrm{~min})$; the plasma was removed and the cells were resuspended in an excess volume of $1 \%$ acetic acid to lyse the erythrocytes. After centrifugation the pellet of leucocytes was washed 3 times with $0.9 \%$ saline. The cells of the pellet were then suspended in a volume of saline equal to that of the pellet, and smears were made from this suspension. The smears were dried and fixed in 1:3 acetic ethanol ready for 
autoradiography. Bone marrow was removed from the ends of the femur and tibia and washed in $0.9 \%$ saline containing $1 \%$ bovine serum albumin. The final pellet was resuspended in an equal volume of $0.9 \%$ saline containing $5 \%$ BSA. The smears, made from this suspension, were dried and fixed in 1:3 acetic ethanol ready for autoradiography.

The synovial lining was dissected from both knee joints and chopped into blocks 1-4 $\mathrm{mm}^{3}$.

\section{A UTORADIOGRAPHY}

For autoradiography the blocks were fixed first in acetic acid:ethanol $(1: 3 \mathrm{v} / \mathrm{v})$ for $1 \mathrm{~h}$ (to remove unincorporated ${ }^{3} \mathrm{HTdR}$ ) and then in buffered formol saline for $24 \mathrm{~h}$. Tissue blocks were then transferred to $70 \%$ ethanol prior to embedding in paraffin. Sections were cut at $4 \mu \mathrm{m}$, mounted on subbed slides, dewaxed, and coated with Ilford $\mathrm{K} 5$ emulsion. The white blood cell and bone marrow smears were also coated with Ilford $\mathrm{K} 5$ emulsion. The slides were exposed for 2 weeks, developed, and then stained with haematoxylin and eosin. Labelling indices were obtained by counting the number of heavily labelled nuclei (that had an almost black autoradiograph) as a proportion of all the synovial lining cell nuclei.

\section{FEULGEN MICRODENSITOMETRY}

Blocks of tissue were chilled by precipitate immersion in n-hexane (BDH 'free from aromatic hydrocarbons' grade, boiling range $67-70^{\circ} \mathrm{C}$ ) at about $-70^{\circ} \mathrm{C}$. Within $1 \mathrm{~min}$ they were transferred to cold dry glass tubes and stored at $-70^{\circ} \mathrm{C}$ until required. Sections were cut at $10 \mu \mathrm{m}$ in a Bright's cryostat with the cabinet temperature between -25 and $-30^{\circ} \mathrm{C}$ and the knife cooled with solid carbon dioxide. ${ }^{5}$ The sections were taken up on to albuminised slides and fixed for $10 \mathrm{~min}$ in acetic acid: ethanol $(1: 3 \mathrm{v} / \mathrm{v})$. They were then left to dry at $37^{\circ} \mathrm{C}$ overnight to ensure that the sections adhered to the slides during the prolonged acid hydrolysis. Serial sections were cut and stained with toluidine blue or haematoxylin and eosin to define the precise histology of the tissue.

For the Feulgen reaction the sections were treated with $5 \mathrm{~N} \mathrm{HC1}$ at room temperature, first for various times up to 90 min to define the optimal time ${ }^{2}$ and then for $30 \mathrm{~min}$ in all subsequent studies. After hydrolysis the sections were washed in $1 \mathrm{~N} \mathrm{HCl}$ and then reacted in the dark with Schiff's reagent (R. A. Lamb) for $1 \mathrm{~h}$. They were then washed in 3 baths of acidic bisulphite, each for $3 \mathrm{~min}$, to remove unreacted leucobasic fuchsin, rinsed in distilled water, left to dry in air, and finally mounted in styrolite (R. A. Lamb). The details of the Feulgen reaction have been described by Chayen et al. ${ }^{5}$

\section{MEAS UREMENT}

The histology was defined by normal microscopy. Generally 100 intact nuclei were measured separately by means of a Vickers M85 scanning and integrating microdensitometer with a $\times 100$ objective (NA $1 \cdot 20$ ), and a scanning spot of $0.25 \mu \mathrm{m}$ in the plane of the specimen, at a wavelength of $550 \mathrm{~nm}$. The size of the scanning field mask was just sufficient to encompass 1 nucleus, as discussed by Bitensky et al. ${ }^{6}$ and Chayen. ${ }^{7}$ The amount of reaction was expressed as relative absorption (recorded by the microdensitometer) per nucleus. The results were plotted as population histograms and the DNA synthesis index ${ }^{2}$ was derived for each population.

Comparison of results from the test and control joints was done by the Student's $t$ test.

\section{Results}

\section{HISTOLOGY}

In the joints challenged with ovalbumin there was an acute inflammatory response which was maximal at 3 days but which was still evident at 5 days after challenge. In the joints injected only with saline patchy infiltrations of polymorphonuclear leucocytes were present after $24 \mathrm{~h}$ but were less evident thereafter.

\section{FEULGEN MICRODENSITOMETRY}

In the synoviocytes of the control (saline-injected) joints of the immunised rabbits, and in those of the totally untreated rabbits, the DNA content per nucleus showed a single modal value, assumably the 2c value, of between 125 and 175 units of relative absorption, with no evidence of DNA synthesis (Figs 1a and e). Even 1 day after the joint had been challenged, and more markedly 3 days after challenge, there was evidence of considerable DNA synthesis, with many nuclei containing appreciably more than the $2 \mathrm{c}$ value. Some contained twice the modal value of the nuclei of the control joints, indicating that they had completed the S-phase of the intermitotic cycle.

The DNA synthesis index was calculated from such histograms for all the rabbit joints studied. In the synovial lining cells of 6 totally untreated rabbits the DNA synthesis index was $3 \cdot 3 \pm 0.6$ (mean \pm SEM), with values ranging from 1.3 to 5.8 . In all the control joints injected with saline in all the rabbits that had been immunised (Table 1) the mean indices were very similar, being $3.9 \pm 0.9$, $4 \cdot 3 \pm 0 \cdot 9$, and $3 \cdot 2 \pm 1 \cdot 4$, with individual values ranging from $1 \cdot 1$ to $7 \cdot 1$. In the other knee of these rabbits there was little change in the DNA synthesis index measured in the synoviocytes 1 day after the intra-articular injection of ovalbumin, though the 
index in one was $\mathbf{9 \cdot 0}$. However, 3 days after intraarticular injection the DNA-synthesis index was markedly raised, each individual value being at least double the highest found in the joints of the same
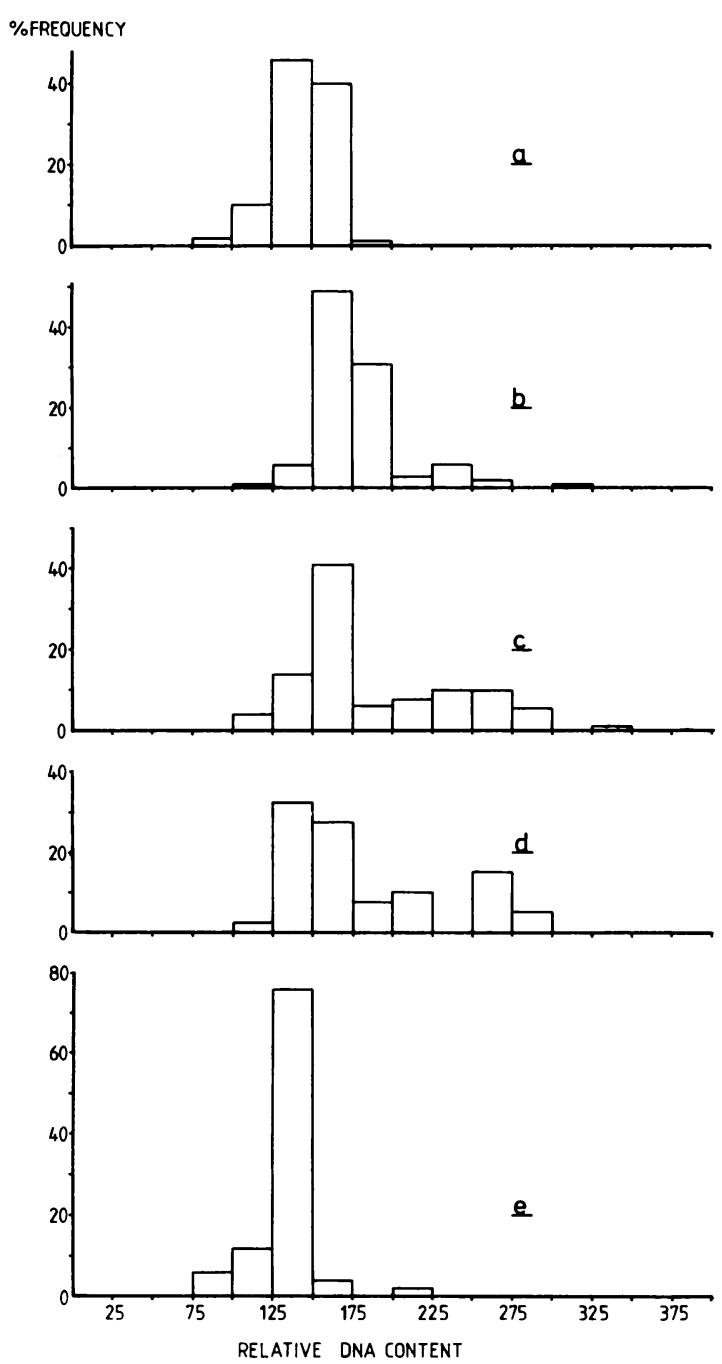

Fig. 1 Population histograms of the amount of the Feulgen reaction (relative DNA content) in individual nuclei of the synovial lining cells taken from the knee joint from (a) an untreated rabbit; (b) a sensitised rabbit 1 day after challenge into this joint; (c) and (d) 2 sensitised rabbits 3 days after ovalbumin had been injected into these joints; and (e) the contralateral knee of $\mathrm{d}$ but injected with saline. Both controls (a and e) show a modal value of about 150 units (relative DNA content), with only 3 nuclei having values above 175 units. In contrast $\mathrm{c}$ and $\mathrm{d}$ show an appreciable part of the population of nuclei with values above 175 units, indicating many cells in $S$ phase.
Table 1 The DNA synthesis index measured in the synovial lining cells of the control and challenged joints of rabbits

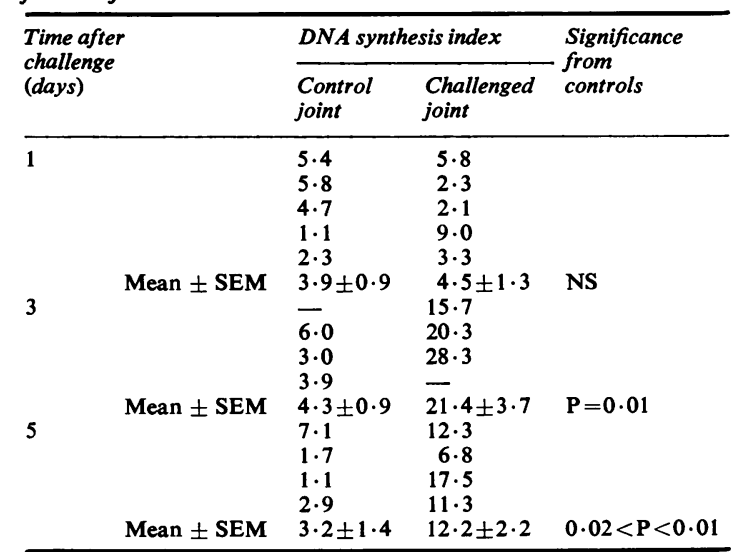

$-=$ Too few synovial lining cells in these preparations.

rabbits injected with saline. Five days after the intra-articular injection the DNA synthesis index was still raised except in 1 rabbit, but it was less than that found 3 days after the injection.

\section{A UTORADIOGRAPHY}

Very few labelled nuclei were found in the synovial lining cells of all the control joints (i.e., those injected with saline) of all the rabbits studied (Table 2). The greatest labelling index that was found in such joints was $1 \%$, most having less than $0.7 \%$ labelled nuclei (i.e., 7 labelled nuclei/1000). One day after the intra-articular injection of ovalbumin into the other knee of such rabbits 1 had a labelling index of $3 \%$

Table 2 The ${ }^{3}$ HTdR labelling index measured in the synovial lining cells of the control and challenged joints of rabbits

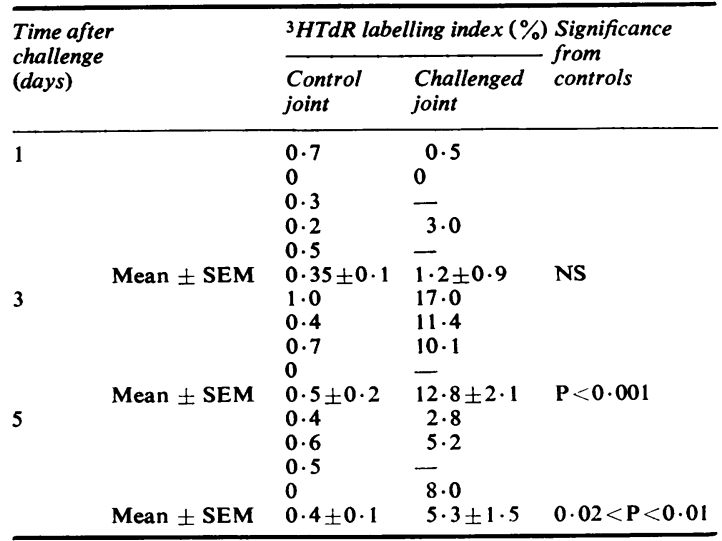

$-=$ Too few synovial lining cells in these preparations. 
in the synoviocytes, but the other 2 that had sufficient numbers of synovial lining cells in the sections measured had low labelling indices. In marked contrast the labelling index of the synovial lining cells in joints 3 days after the injection of ovalbumin was considerably raised, so that at least 1 in every 10 synoviocytes was heavily labelled. The labelling index declined 5 days after the challenge but was still higher than in the control joints of the same rabbits.

No labelled nuclei were found in the autoradiographs of the smears of circulating blood or of the bone marrow taken from the tibia and femur.

\section{Discussion}

In synovial tissue from human joints affected by rheumatoid arthritis ${ }^{8}$ and from the affected joint in the rabbit subjected to experimental immune arthritis $^{9}$ the synovial lining is considerably thickened. Yet in studies that have been made on synovial tissue taken from rheumatoid joints, whether studied by Feulgen cytophotometry ${ }^{210}$ or by tritiated thymidine autoradiography, ${ }^{11}$ the DNA synthetic activity of the rheumatoid synoviocytes has been shown to be only equivalent to that of their nonrheumatoid counterparts. It was therefore possible to doubt whether or not the synoviocytes were capable of synthesising DNA in sufficient quantity and at a sufficient rate to allow these cells to proliferate.

In the present study DNA synthesis in the lining cells of rabbit synovium has been measured by 2 different procedures. The first was Feulgen cytophotometry of the amount of DNA per nucleus in the synovial lining cells. The amount of DNAsynthesis was quantified by the DNA-synthesis index of Coulton et al..$^{2}$ The second involved the uptake of radioactively labelled thymidine and its incorporation into DNA: this was quantified by the labelling index, namely, by the proportion of nuclei of the synovial lining cells that showed a strong autoradiograph. The tritiated thymidine was administered in vivo into the joint $3 \mathrm{~h}$ before the rabbit was killed, so that only cells that were in $\mathbf{S}$ phase would be labelled. The small amount of radioactively labelled thymidine that was injected, namely, $10 \mu \mathrm{Ci}$ into each joint, had been shown by Loewi et al. ${ }^{4}$ to be too small to escape in sufficient concentration to label cells outside the joint. In agreement with the work of Loewi et al., ${ }^{4}$ and in spite of the fact that bone marrow avidly takes tritiated thymidine from the circulation, ${ }^{12}$ no uptake of the label was found in the present study in smears made from the nearby bone marrow or from the circulating blood.

In agreement with previous findings in human synovial tissue, evidence of only a little DNA synthesis was found in the synoviocytes of untreated rabbit knee joints or of joints that had been injected with saline (Fig. 1; Tables 1 and 2). Thus the DNA synthesis index in the former was $3.3 \pm 0.6$ and in the latter $3 \cdot 2 \pm 1 \cdot 4$ to $4 \cdot 3 \pm 0.9$; the autoradiographic labelling indices in the saline injected joints did not exceed $1.0 \%$. On the first day after the intra-articular challenge these indices showed little or no change. However, on the third day after challenge the DNA synthesis index rose to around 20 , which is the value found in rapidly regenerating tissues such as guinea-pig epidermis regenerating after wound healing. ${ }^{213}$ Equivalently, the autoradiographic labelling index rose to over $10 \%$, indicating that 1 cell in 10 was in $S$ phase. Thus there was strong evidence of considerable DNA synthetic activity in these synoviocytes, compatible with preparation for cellular proliferation. The fact that only few mitotic figures were seen in these preparations could reflect merely the possibility that the time of day at which mitoses occur is different from that at which the samples were taken. The advantage of measuring DNA synthesis is the fact that in general $S$ phase occupies a much longer time than the process of mitosis, so that there is more likelihood of measuring it than there is of catching the wave of mitoses.

Even 5 days after challenge both indices were well above the control values but had declined from the high values found 3 days after challenge. Thus the further development of the synovial hyperplasia found at later times in the rabbit model requires more investigation. However, these results seem to indicate that the apparently differentiated synovial lining cells, identified very readily by their histological appearance and location in these studies, are capable of DNA synthesis for cellular division.

We are grateful to the Medical Research Council for specific support for this work and to the Arthritis and Rheumatism Council for Research for general support. We also acknowledge the technical help of Miss I. R. Ellis.

\section{References}

1 Mohr W, Beneke G, Mohing W. Proliferation of synovial lining cells and fibroblasts. Ann Rheum Dis 1975; 34: 219-24.

2 Coulton L A, Henderson B, Bitensky L, Chayen J. DNA synthesis in human rheumatoid and nonrheumatoid synovial lining. Ann Rheum Dis 1980 ; 39 : 241-7.

3 Consden R, Doble A, Glynn L E, Nind A P. Production of a chronic arthritis with ovalbumin. Ann Rheum Dis $1971 ; 30$ : 307-15.

4 Loewi G, Dorling J, Glynn L E. The origin of antibodyproducing cells in experimental synovitis. Int Arch Allergy $1971 ; 41$ : $132-7$.

5 Chayen J, Bitensky L, Butcher R G. Practical Histochemistry. New York and L ondon: Wiley, 1973. 
${ }^{6}$ Bitensky L, Butcher R G, Chayen J. Quantitative cytochemistry in the study of lysosomal function. In: Dingle $\mathrm{J}$, ed. Lysosomes in Biology and Pathology. Amsterdam: North Holland, $1975 ; 3$ : 465-510.

7 Chayen J. Microdensitometry. In: Slater T F, ed. Biochemical Mechanisms of Liver Injury. London and New York: Academic Press, 1978: 257-96.

8 Gardner D L. Pathology of the Connective Tissue Diseases. London: Edward Arnold, 1965.

9 Gall E P, Gall E A. Histopathogenesis of bovine serum albumin-induced arthritis in the rabbit. $J$ Rheumatol $1980 ; 7: 13-23$.

${ }^{10}$ Mohr W, Beneke G, Mohing W. Zytophotometrische untersuchungen zur Proliferation der Synovialzellen (lining cells) bei rheumatoider Arthritis. $Z$ Rheumatol $1973 ; 32$ : 428-40.

11 Nykänen P, Helve T, Kankaanpää U, Larsen A. Characterization of the DNA-synthesizing cells in rheumatoid synovial tissue. Scand J Rheumatol 1978; 7: 118-22.

12 Plager $J$. The induction of transient increases in mitotic rate in murine tissues following prolonged intravenous infusions of hydroxyurea. Cell Tissue Kinet 1975; 8: 517-28.

13 Coulton L A. The cytochemical measurement of DNA and its synthesis with particular reference to its involvement in rheumatological problems. PhD thesis, Brunel University, 1977. 